\title{
ASSESSEMENT OF GROUNDWATER CONTAMINATION WITH HEAVY METALS IN RURAL AREA. CASE STUDY OF BAREBUHAR VILLAGE, DUHOK GOVERNORATE, KURDISTAN REGION OF IRAQ
}

\author{
NABAZ IBRAHEEM MOHAMMED \\ Dept. of Recreation and Ecotourism, College of Agricultural Engineering Science, \\ University of Duhok, Kurdistan Region-Iraq
}

(Received: July 23, 2019; Accepted for Publication: October 16, 2019)

\begin{abstract}
Heavy metals are considered dangerous due to their tendency to bioaccumulate in a biological organism (tissues) over time. Their toxicity can result in damaged or reduced central nervous function, energy levels, lungs, kidneys, liver and other vital organs. This study was conducted to determine some heavy metals levels $(\mathrm{Mn}, \mathrm{Pb}, \mathrm{Cu}, \mathrm{Co}, \mathrm{Ni}$, and $\mathrm{Zn}$ ) in 15 deferent water sources collected from Barebuhar village, Duhok governorate. The concentration of heavy metals was determined via atomic spectrophotometer. The obtained results show that $\mathrm{Mn}$ and $\mathrm{Pb}$ concentration in some water sample were higher than recommended levels set by deferent organization such as WHO, EPA, and EC for drinking water. Since the concentrations of these heavy metals were above the standard levels in some water sources, these high levels can cause the adverse effects on human health if the water from these sources taken for drinking purposes. Also high concentrations physico-chemical parameters like EC (up to 2399 $\mu \mathrm{S} / \mathrm{cm}$ ) and TDS (up to $1243 \mathrm{mg} / \mathrm{l}$ ) were detected in some water sample above permissible levels for drinking purposes.
\end{abstract}

KEYWORDS: Heavy metals, Contamination, Lead, Drinking water, Groundwater https://doi.org/10.26682/ajuod.2019.22.2.10

\section{INTRODUCTION}

$\mathbf{I}$ $\mathrm{n}$ arid and semi-arid regions, water is becoming one of the major environmental issues due to drought sensitivity, increasing consumption, and high rate of contamination (Ragab and Prudhomme, 2002; Yousuf et al., 2018; Mohammed and Bamarni, 2019). Water resources contaminants such as toxic (heavy) metals, nitrates and salt have found their way into water resources due to insufficient treatment and disposal of waste (human and livestock), industrial discharges, use of chemical fertilizer and pesticide in agriculture, and over-use of limited water resources (Singh and Mosley, 2003). Moreover, natural sources are also likely to contribute higher levels of metals and other chemicals that can negatively affect human health. Various trace elements are micronutrient for living system, their absence or surplus can impact adversely human body (Jinwal et al., 2009), while, some heavy metals can be toxic even at low concentration because of their tendency to accumulate in the body tissue (Domenico and Schwartz, 1998). Heavy metals in groundwater are generally dissolved in very minute quantities in most of the cases and its concentration is less than $1 \mathrm{mg} / \mathrm{l}$ (USGS, 1993).

Therefore, groundwater pollution and its management has become the need of time since its reaching influence on human well-being. The examination of heavy metal concentrations in water resources is required to provide important information on human influence on the environment and serve as an indicator of pollutant loading (Bayan and Mustafa, 2018; Mustafa et al., 2018).

The main goal of this work is to determine the concentration of some of the physicochemical parameters ( $\mathrm{pH}, \mathrm{EC}$, and TDS) and heavy metals $(\mathrm{Mn}, \mathrm{Pb}, \mathrm{Co}, \mathrm{Cu}, \mathrm{Ni}$, and $\mathrm{Zn}$ ) in groundwater resources and springs of the Barebuhar village, Duhok governorate, Kurdistan region of Iraq and to compare the values with the international organizations (such as WHO) recommended drinking water standards. This study is useful in local and regional scale for water resource management mainly in rural area.

\section{MATERIAL AND METHOD}

\subsection{Study area}


The study was conducted in Barebuhar village which is situated $10 \mathrm{Km}$ northeast of Duhok city (Figure 1). The study area is considered as a semi-arid region with temperatures ranging between 1.0 and $40{ }^{\circ} \mathrm{C}$. The average annual precipitation is about $760 \mathrm{~mm}$ and rainy season start from September to May with the climate similar to Mediterranean region. Geographically, the study area is located between $36^{\circ} 52^{\prime} 42.276^{\prime \prime}$ North and $43^{\circ} 5^{\prime} 50.0388^{\prime \prime}$ East. This village is chosen for this study because it is considered to be well known for intensive cultivating of vineyards, therefore, farmer uses vast quantities of different pesticides and fertilizers that could deteriorate water resource quality (Nerway, 2011).

\subsection{Sampling and analysis}

A total of 15 different water sampling points (3 springs, 4 surface wells, and 8 boreholes) were selected to represent the water quality in the study area. The coordinates and locations of these points are summarized in Table 1 and Figure1. Water taken once from each selected points during September 2018 and water samples were collected in polyethylene bottle (0.5 litre capacity) under sterile conditions. Water samples were stored in cold condition with temperature around $4{ }^{\circ} \mathrm{C}$ and delivered in the same day to the laboratory of the Directorate of the Environment of Dohuk city and analysis were performed within 24 hours of sampling date to avoid any possible changes in water quality parameters. Water temperature $(\mathrm{T}), \mathrm{pH}$, electrical conductivity (EC), and total dissolved solids (TDS) were recorded in the field by using a portable multi-metre (Trans ISO 9002). The water samples were analysed for 6 heavy metals including manganese $(\mathrm{Mn})$, lead $(\mathrm{Pb})$, cobalt $(\mathrm{Co})$, copper $(\mathrm{Cu})$, nickel $(\mathrm{Ni})$, and zinc $(\mathrm{Zn})$ by using atomic spectrophotometer.

Table 1. Coordinates and depths of the sampling points

\begin{tabular}{cccc}
\hline Sample ID & Latitude & Longitude & Depth (m) \\
\hline S1 & $36^{\circ} 52^{\prime} 52.6116^{\prime \prime}$ & $43^{\circ} 6^{\prime} 11.1816^{\prime \prime}$ & - \\
\hline S2 & $36^{\circ} 52^{\prime} 42.3732^{\prime \prime}$ & $43^{\circ} 6^{\prime} 30.8592^{\prime \prime}$ & - \\
\hline S3 & $36^{\circ} 52^{\prime} 29.8992^{\prime \prime}$ & $43^{\circ} 6^{\prime} 33.0372^{\prime \prime}$ & - \\
\hline SW1 & $36^{\circ} 52^{\prime} 30.9576^{\prime \prime}$ & $43^{\circ} 6^{\prime} 5.9544^{\prime \prime}$ & 3 \\
\hline SW2 & $36^{\circ} 52^{\prime} 30.4932^{\prime \prime}$ & $43^{\circ} 6^{\prime} 9.4788^{\prime \prime}$ & 3 \\
\hline SW3 & $36^{\circ} 52^{\prime} 25.2984^{\prime \prime}$ & $43^{\circ} 5^{\prime} 49.3368^{\prime \prime}$ & 1 \\
\hline SW4 & $36^{\circ} 52^{\prime} 30.9504^{\prime \prime}$ & $43^{\circ} 5^{\prime} 52.3752^{\prime \prime}$ & 1 \\
\hline B1 & $36^{\circ} 52^{\prime} 24.8376^{\prime \prime}$ & $43^{\circ} 5^{\prime} 46.6728^{\prime \prime}$ & 85 \\
\hline B2 & $36^{\circ} 52^{\prime} 39.0288^{\prime \prime}$ & $43^{\circ} 5^{\prime} 43.8252^{\prime \prime}$ & 140 \\
\hline B3 & $36^{\circ} 52^{\prime} 42.276^{\prime \prime}$ & $43^{\circ} 5^{\prime} 50.0388^{\prime \prime}$ & 135 \\
\hline B4 & $36^{\circ} 52^{\prime} 46.8696^{\prime \prime}$ & $43^{\circ} 6^{\prime} 2.1852^{\prime \prime}$ & 95 \\
\hline B5 & $36^{\circ} 52^{\prime} 51.1392^{\prime \prime}$ & $43^{\circ} 5^{\prime} 53.4948^{\prime \prime}$ & 125 \\
\hline B6 & $36^{\circ} 52^{\prime} 41.07^{\prime \prime}$ & $43^{\circ} 6^{\prime} 9.7128^{\prime \prime}$ & 95 \\
\hline B7 & $36^{\circ} 52^{\prime} 41.0448^{\prime \prime}$ & $43^{\circ} 5^{\prime} 59.6256^{\prime \prime}$ & 100 \\
\hline B8 & $36^{\circ} 52^{\prime} 45.912^{\prime \prime}$ & $43^{\circ} 5^{\prime} 47.1876^{\prime \prime}$ & 170 \\
\hline & & &
\end{tabular}




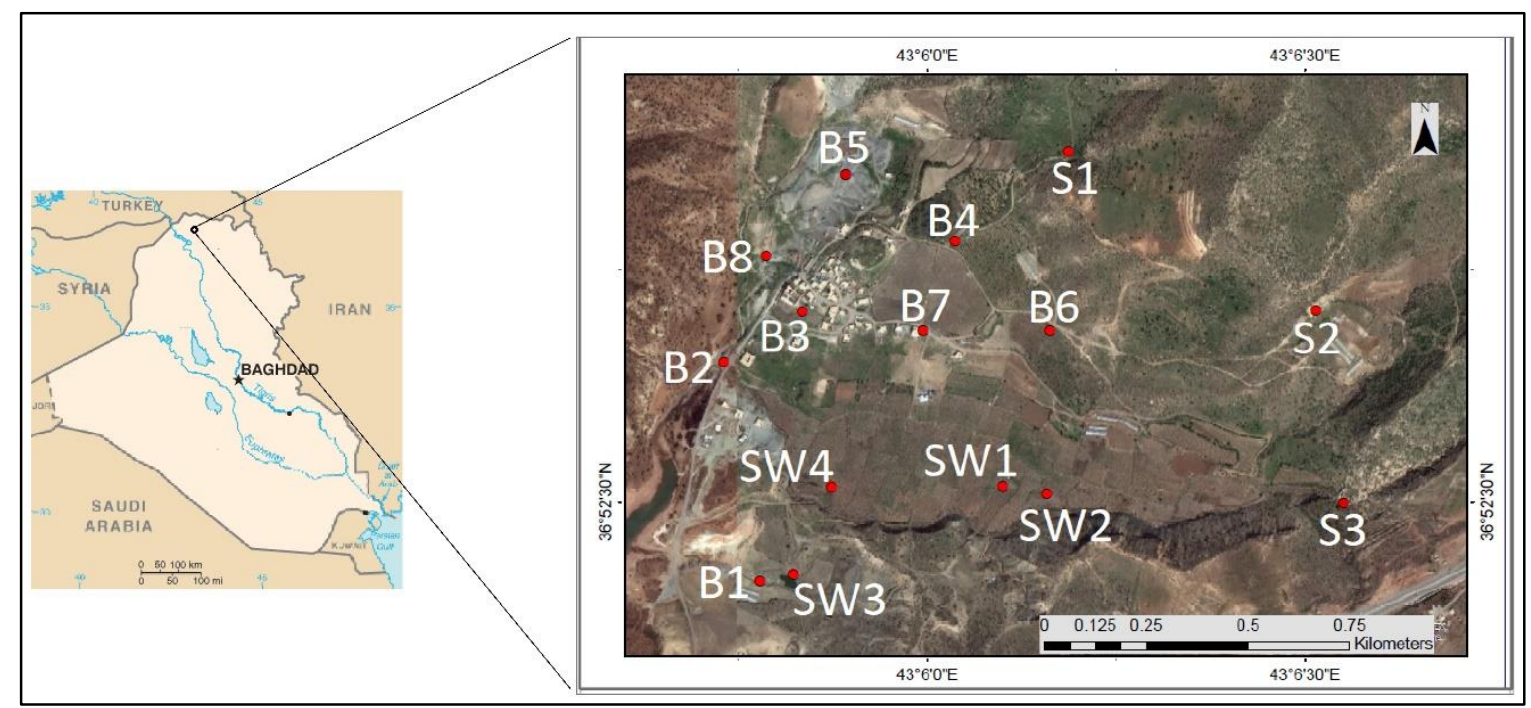

Fig. (1): Study area location illustrating sampling points

\section{RESULT AND DISCUSION}

The measured concentration of physicochemical and heavy metals in both springs and groundwater are given in Table 2 . The $\mathrm{pH}$ was measured at the sampling collection site which measures the acidity or alkalinity condition of water body and is a good indicator of the water quality (UNEP GEMS, 2008). The values of $\mathrm{pH}$ range between 7.7 and 8.5 that show all of the water samples are slightly alkaline possibly due to presence high concentration of carbonates and bicarbonates in the geological formation of the study area (Mohammed and Bamarni, 2019). From human consumption point of view, the samples may be considered fit as they were found within the limit $(6.5-8.5)$ for drinking prescribed by WHO (2008) and EC (1998) admissible limit $(6.5-9.5)$. The temperature of water samples were in the range of 21.8 to $32^{\circ} \mathrm{C}$.

The Electrical conductivity (EC) is a measure of saltiness of the water and is a good indicator of the presence of contaminants in water body.
The range of EC value of the water samples vary from $507-2399 \mu \mathrm{S} / \mathrm{cm}$ (Figure 2). Freshwater is usually has EC value less than $1500 \mu \mathrm{S} / \mathrm{cm}$ (WHO, 2008), only four groundwater samples have concentrations higher than this value (SW2, SW3, SW4, B7). There is no health related limit for TDS in drinking water, however, palatability of water with TDS concentration below $500 \mathrm{mg} / \mathrm{l}$ is generally considered to be good (WHO, 2008). Drinking water becomes significantly and progressively unpalatable at TDS concentrations greater than about $1000 \mathrm{mg} / \mathrm{l}$. According to London et al. (2005), the level higher than 1200 $\mathrm{mg} / \mathrm{l}$ may be objectionable to consumers and could have impacts for those who have to limit their daily salt intake such as severely hypertensive, diabetic, and renal dialysis patients. Of the 15 samples analysed, 12 were found to contain TDS concentration of greater than $500 \mathrm{mg} / \mathrm{l}$ and the highest concentration $(1243 \mathrm{mg} / \mathrm{l})$ was recorded in surface well (SW3) which is not used for drinking purposes (Figure 2).

Table (2):Concentrations, means and standard deviations of physical parameters and heavy metals from urban area of Barebuhar village.

\begin{tabular}{ccccccccccc}
\hline $\begin{array}{c}\text { Sample } \\
\text { ID }\end{array}$ & ToC & $\mathbf{p H}$ & $\begin{array}{c}\mathrm{EC} \\
\mathbf{S} / \mathbf{c m}\end{array}$ & $\begin{array}{c}\mathrm{TDS} \\
\mathbf{m g} / \mathbf{l}\end{array}$ & $\begin{array}{c}\mathbf{M n} \\
\mathbf{m g} / \mathbf{l}\end{array}$ & $\begin{array}{c}\mathbf{P b} \\
\mathbf{m g} / \mathbf{l}\end{array}$ & $\begin{array}{c}\mathbf{C o} \\
\mathbf{m g} / \mathbf{l}\end{array}$ & $\begin{array}{c}\mathbf{C u} \\
\mathbf{m g} / \mathbf{l}\end{array}$ & $\begin{array}{c}\mathbf{N i} \\
\mathbf{m g} / \mathbf{l}\end{array}$ & $\begin{array}{c}\mathbf{Z n} \\
\mathbf{m} / \mathbf{l}\end{array}$ \\
\hline S1 & 24 & 8.2 & 507 & 263 & 0.092 & 0.026 & 0.027 & 0.042 & N.D & N.D \\
\hline S2 & 28.9 & 8.1 & 523 & 271 & 0.181 & 0.107 & 0.009 & 0.032 & N.D & N.D \\
\hline S3 & 25.8 & 8 & 1198 & 599 & 0.018 & 0.034 & 0.019 & 0.170 & N.D & 0.006 \\
\hline SW1 & 27.3 & 7.8 & 1255 & 639 & 0.202 & 0.091 & 0.017 & 0.094 & N.D & 0.009 \\
\hline
\end{tabular}




\begin{tabular}{ccccccccccc}
\hline SW2 & 29.9 & 7.9 & 1701 & 859 & 0.092 & 0.164 & 0.010 & 0.106 & N.D & N.D \\
\hline SW3 & 32 & 8.5 & 2399 & 1243 & 0.062 & 0.263 & 0.021 & 0.142 & 0.015 & 0.052 \\
\hline SW4 & 27 & 8.4 & 1723 & 887 & 0.410 & 0.173 & 0.009 & 0.102 & N.D & N.D \\
\hline B1 & 22.5 & 8.3 & 1232 & 643 & 0.011 & 0.163 & N.D & 0.170 & N.D & N.D \\
\hline B2 & 21.8 & 8.5 & 1006 & 501 & 0.010 & 0.046 & N.D & 0.121 & N.D & 0.012 \\
\hline B3 & 23.6 & 8.1 & 1073 & 523 & 0.024 & 0.067 & N.D & 0.136 & N.D & N.D \\
\hline B4 & 23.3 & 8.2 & 1459 & 766 & 0.039 & 0.116 & 0.009 & 0.136 & N.D & N.D \\
\hline B5 & 24.6 & 7.9 & 908 & 470 & 0.152 & 0.428 & 0.008 & 0.117 & N.D & N.D \\
\hline B6 & 24.3 & 7.8 & 1073 & 564 & 0.119 & 0.118 & 0.036 & 0.217 & N.D & 0.008 \\
\hline B7 & 26.5 & 7.6 & 1601 & 860 & 0.121 & 0.170 & 0.041 & 0.310 & N.D & 0.009 \\
\hline B8 & 26.7 & 7.7 & 981 & 508 & 0.022 & 0.173 & 0.002 & 0.109 & N.D & N.D \\
\hline Mean & 25.9 & 8.27 & 1242.6 & 639.7 & 0.104 & 0.143 & 0.017 & 0.134 & 0.015 & 0.016 \\
\hline SD & 2.86 & 0.49 & 486.3 & 253.8 & 0.106 & 0.102 & 0.012 & 0.068 & -- & 0.018 \\
\hline
\end{tabular}

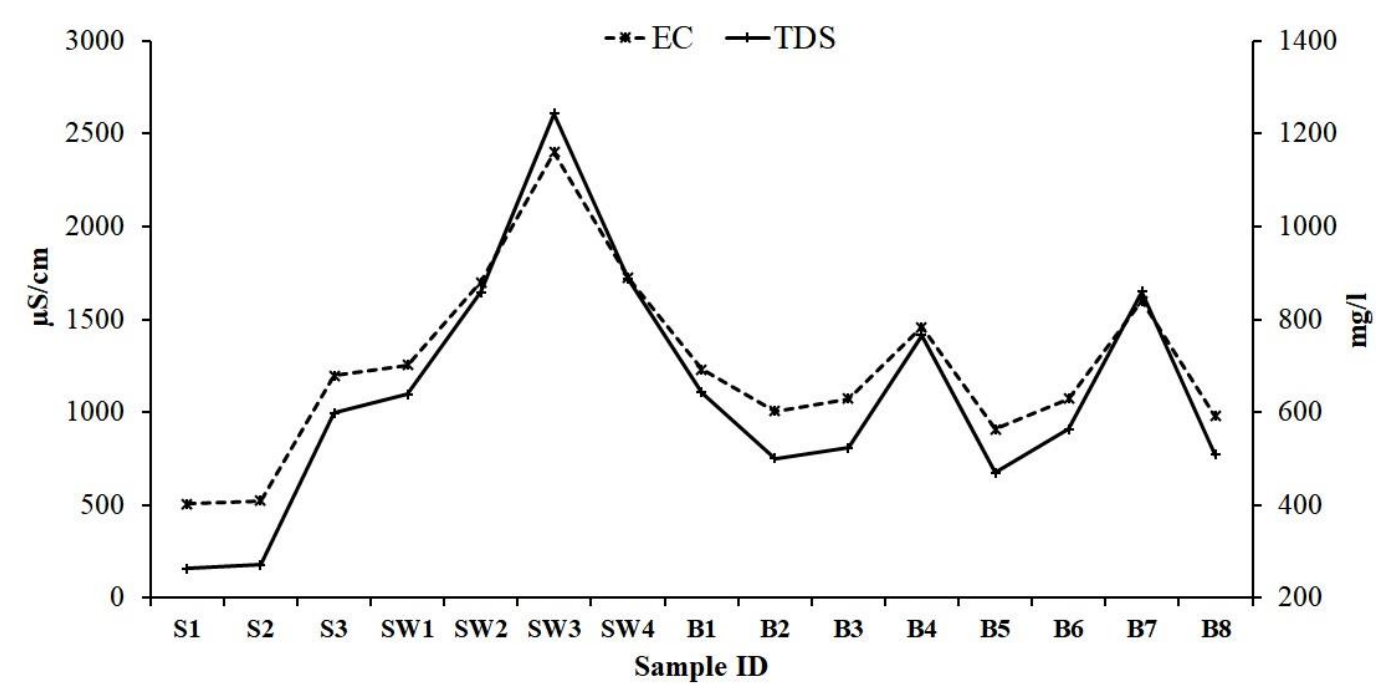

Fig. (2): The concentrations of electrical conductivity (EC) and total dissolved solids (TDS) of sampled water.

Guidelines for the presence of heavy metals in drinking water have been set by different international organizations such as US EPA, WHO, European Union Commission. Manganese (Mn) is an abundant trace metal in the environment, it is a minor constituent of most rock types and also available in soils from weathering and aerial deposition. Naturally occurring $\mathrm{Mn}$ is widely detected in drinking water supplies and is important for human health at low concentrations (Keen and ZidenbergCherr, 1994). The world Health Organization (WHO) guideline for Mn set at value of $0.4 \mathrm{mg} / \mathrm{l}$ (WHO, 2011), however, most countries have set a lesser limit mainly due to aesthetic and infrastructure problems. For instance, European Committee (EC) and Environmental Protection Agency (EPA) have listed Mn as an indicator at a concentration of $0.05 \mathrm{mg} / \mathrm{l}$ in drinking water (EC, 1998; EPA, 2007). In this study, there was a wide variation in $\mathrm{Mn}$ concentrations and ranged between $0.010-0.410 \mathrm{mg} / \mathrm{l}$ (Table 2 and

Figure 3). The European Committee limit for Mn drinking water of $0.05 \mathrm{mg} / \mathrm{l}$ was exceeded in 9 water samples; the WHO health guideline of $0.40 \mathrm{mg} / \mathrm{l}$ was exceeded in only one water sample (SW4). Canada Health (2016) concluded that a Mn concentration between 0.01 to 0.02 $\mathrm{mg} / \mathrm{l}$ is a suitable limit to keep against the discolouration of water. This is supported by many studies of drinking water that have stated that consumer complaints about discoloured water and/or staining of laundry occur at $\mathrm{Mn}$ values exceeding $0.02 \mathrm{mg} / \mathrm{l}$ (Sly et al., 1990; Casale et al., 2002; Kohl and Medlar, 2006). Both surface and groundwater sources of $\mathrm{Mn}$ can 
be natural (rock and soil weathering) and manmade (industrial discharge, mining activities and landfill leaching) (Stokes et al., 1988; Kohl and Medlar, 2006; Ljung and Vahter, 2007). High concentrations of $\mathrm{Mn}$ in this study could be naturally and man-made particularly landfill leaching and agricultural activities such as pesticides since the area is widely used for grape cultivation (Nerway, 2011).

Lead $(\mathrm{Pb})$ is highly toxic metals and it should normally be available merely in trace amount. Lead shows toxicity to nervous system, accumulate in kidney and skeleton, and reproductive system. Over exposure to lead could cause permanent brain damage, and newborn babies are more sensitive than the adults (Jennings et al., 1996). The concentrations of lead were found to be maximum of $0.428 \mathrm{mg} / \mathrm{l}$ at
B5 and minimum of $0.026 \mathrm{mg} / \mathrm{l}$ at $\mathrm{S} 1$. It is seen that all the samples has lead concentration above the WHO standard of 0.01ppm (WHO, 2008). The elevated level of lead in the groundwater and springs of the study area may highly be the result of entry from agricultural run-off containing phosphatic fertilizers and also from intensive pesticide application to grape farms (Abdul Jameel et al., 2012; Assubaie, 2015).

Cobalt (Co) concentration was found to be below the detected limit in three water samples (B1, B2, and B3). In the other samples, cobalt value ranges from 0.002 and $0.041 \mathrm{mg} / \mathrm{l}$. Nevertheless the maximum admissible limit of cobalt is not mentioned by WHO (2008), all the samples analysed comply the EPA (2007) maximum admissible limits of cobalt in drinking water

$\mathrm{mg} / \mathrm{l})$.

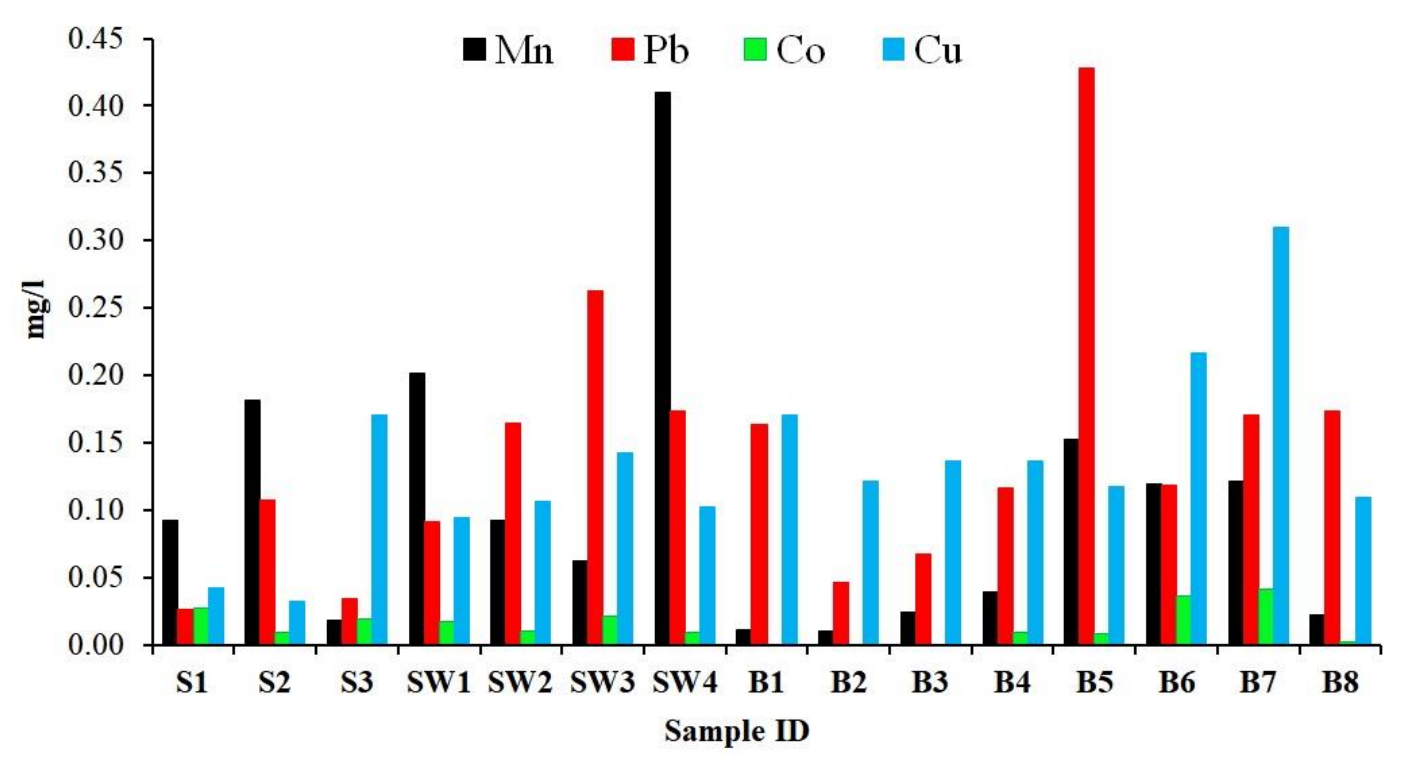

Fig. (3): The concentration of heavy metals in water samples.

Copper $(\mathrm{Cu})$ is an important trace element and needed by biological systems for some enzymes stimulation through the process of photosynthesis, however, at elevated concentrations it shows detrimental influences on the human body and may cause nausea and diarrhea. $\mathrm{Cu}$ is also lethal to a range of aquatic organisms even at very small concentrations. The presence of copper in water resources can be from mining, metallurgy, industrial uses, copper salts for algae control, and corrosion of copper pipes (Sharma, 2015, Kashin and Ivanov, 2008). The concentration of $\mathrm{Cu}$ in water samples varied from 0.032 to $0.310 \mathrm{mg} / \mathrm{l}$, these values are lower than the maximum admissible level of $2 \mathrm{mg} / \mathrm{l}$ for drinking water set by WHO (2008) and $1.0 \mathrm{mg} / \mathrm{l}$ set by EPA (2007). 


\section{CONCLUSION}

This study shows that the water collected from 15 water sources from Barehuhar village consists of elevated concentrations of heavy metals mainly manganese and lead which were found to surpass the maximum permissible limits set by various organization such as WHO, EPA, and EC. It was also found that cobalt and cupper exist in most samples but in lower concentrations and within permissible level of drinking water. Chemical fertilizers, pesticides, waste water in some extend and rock mineral dissolution could be the main causes of high level of some toxic elements in water samples. Therefore, the results of this study approve the water contamination and hence without prior treatment water should not be consumed, nevertheless water sources are suitable for agricultural activities.

\section{REFERENCES}

Abdul Jameel A., Sirajudeen J., and Abdul vahith R. (2012). Studies on heavy metal pollution of ground water sources between Tamilnadu and Pondicherry, India. Advances in Applied Science Research, Vol 3 (1): 424-429.

Assubaie, F. N. (2015). Assessment of the levels of some heavy metals in water in Alahsa Oasis farms, Saudi Arabia, with analysis by atomic absorption spectrophotometry. Arabian Journal of Chemistry, Vol 8(2), 240-245.

Bayan A. Abdulhalim and Mustafa I. Umer 2018. Effects of Chemical and Physical Properties of Pond Bottom Sediments on Fish Rearing in Iraqi Kurdistan Region. Kufa Journal for Agriculture Science. Kufa, Iraq Vol (10)3 $: 99-78$

Canada Health (2016). Manganese in drinking water. Document for public consultation. Prepared by the Federal-Provincial-Territorial Committee on Drinking Water.

Casale, R.J., LeChevallier, M.W. and Pontius, F.W. (2002). Manganese control andvrelated issues. American Water Works Research Foundation and American Water Works Association. Denver, Colorado.
Domenico PA, Schwartz FW (1998). Physical and Chemical Hydrogeology, $2^{\text {nd }}$ Edition. John Wiley and Sons, INC. p. 495.

Environmental Protection Agency (EPA) (2007). Framework for Metals Risk Assessment. Office of the Science Advisor, Risk Assessment Forum, U.S. Environmental Protection Agency, Washington, DC 20460.

European Commission (EC) (1998). Council Directive 98/83/EC of 3 November 1998 on the quality of water intended for human consumption. Official Journal 1998; L330: 3254.

Jennings G.D., Sneed R.E., Clair M.B. St (1996). Metals in drinking water. Published by: North Carolina Cooperative Extension service Publication no.: AG-473-1. Electronic version 3/1996.

Jinwal A., Dixit S., Malik S. (2009). Some Trace Elements Investigation in Ground Water of Bhopal and Sehore District in Madhya Pradesh: India. J. Appl. Sci. Environ. Manage., Vol 13(4): 47-50.

Kashin V. K. and Ivanov G. M. (2008). Copper in Natural Waters in Transbaikalia. Water Resources, Vol 35 (2): 228-233.

Keen C.L., Zidenberg-Cherr S. (1994). Manganese toxicity in humans and experimental animals. In: Klimis-Tavantzis DJ, editor. Manganese in Health and Disease. London: CRC Press; p. 193-205.

Kohl, P.M. and Medlar, S.J. (2006). Occurrence of manganese in drinking water and manganese control. American Water Research Foundation, American Water Works Association and IWA Publishing. Denver, Colorado.

Ljung, K. and Vahter, M. (2007). Time to re-evaluate the guideline value for manganese in drinking water? Environ. Health Perspect., 115(11): $1533-1538$

Mustafa I. Umer , Payman A. Abduljabar, and Newar A. M. Hamid (2018) .Assessment of ground water pollution by heavy metals and anions in Kwashe industrial area, Duhok City, Kurdistan Region. Iraq. IOP Conf. Series: Materials Science and Engineering 454 (2018) 012004 doi:10.1088/1757$899 X / 454 / 1 / 012004.1$ 
Mohammed, N., and K. Bamarni (2019). "Water Quality Monitoring of Duhok Dam (Kurdistan Region of Iraq)". ZANCO Journal of Pure and Applied Sciences, Vol. 31, no. 1, Feb. 2019, pp. 7-16, doi:10.21271/ZJPAS.31.1.2.

Nerway H.M.S. (2011). Effect of foliar spraying of some organic fertilizers on growth, yield and quality of grape CV. Rash-Mew (Vitis vinifera L.) under non-irrigated conditions. MSc thesis. College of agriculture, University of Duhok.

Ragab R. and Prudhomme C. (2002). Climate Change and Water Resources Management in Arid and Semi-arid Regions: Prospective and Challenges for the 21st Century. Biosystems Engineering Vol 81 (1), 3-34

Sharma S., K. (2015). Heavy Metals in Water: Presence, Removal, and Safety. The royal Society of Chemistry. Cambridge, UK.

Singh S., Mosley L.M. (2003). Trace metal levels in drinking water on Viti Levu, Fiji Islands. $S$. Pac. J. Nat. Sci., Vol 21:31-34.

Sly, L.I., Hodgkinson, M.C., Arunpairojana, V. (1990). Deposition of manganese in drinking water distribution systems. Appl. Environ. Microbiol., 56(3), 628-639.
Stokes, P.M., Campbell, P.G.C., Schroeder, W.H., Trick, C., France, R.L., Puckett, K.J., LaZerte, B., Speyer, M., Hanna, J.E. and Donaldson, J. (1988). Manganese in the Canadian environment. NRCC (ed.).

UNEP GEMS (2008). Water quality for ecosystem and human health. $2^{\text {nd }}$ edition, Ontario, Canada.

USGS (1993). National water Summary-1990- 1991: Stream Water Quality U.S.Geol. Surv. Water Supply paper No. 2400, p. 590.

WHO (World Health Organization) (2008). "Guidelines for Drinking Water Quality," $3^{\text {rd }}$ Edition, Geneva.

WHO (World Health Organization) (2011). "Manganese in drinking water," Background document for development of WHO Guidelines for Drinking-water Quality, Geneva.

Yousuf M. A., Rapantova N., Younis J. H. (2018). Sustainable Water Management in Iraq (Kurdistan) as a Challenge for Governmental Responsibility. Water Vol 10: 1651 


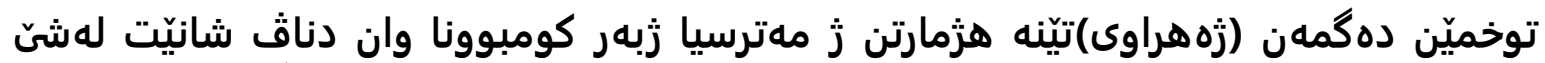

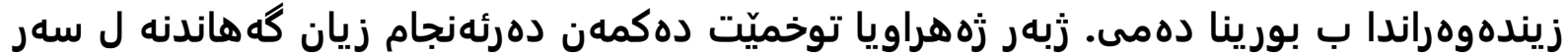

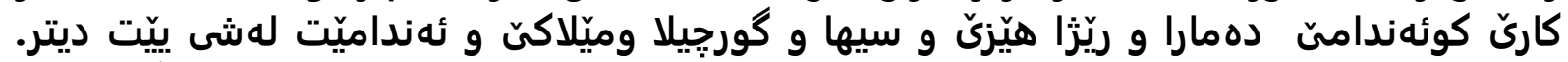

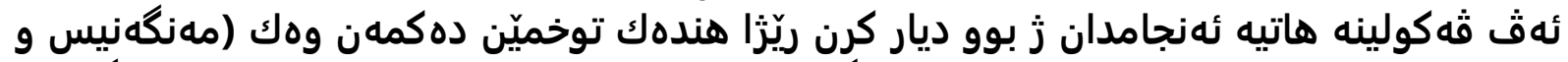

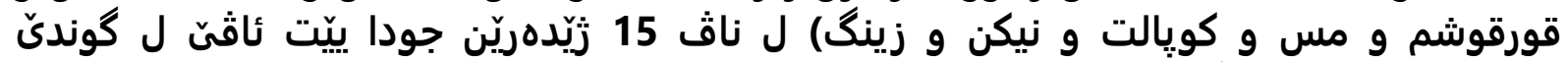

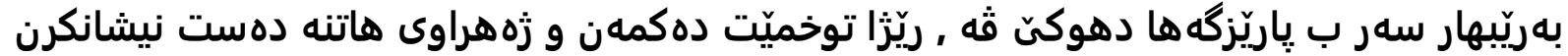

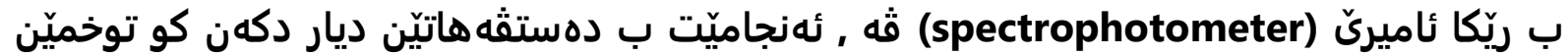

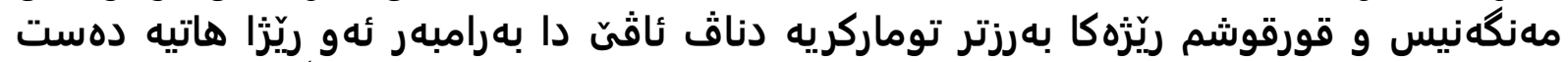

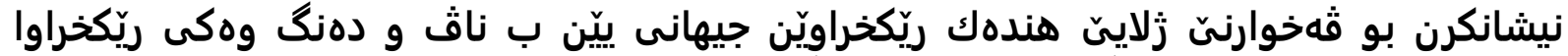

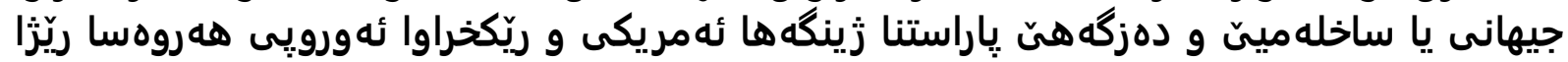

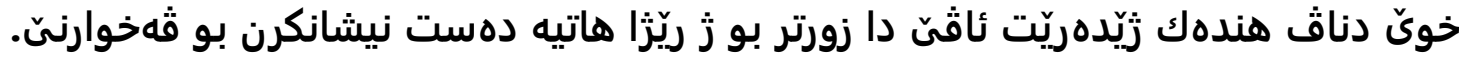

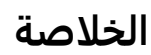

تعتبر المعادن الثقيلة خطره على الكائنات الحية اذا ما تم استهلاكها بسبب تراكمها في الإلياء

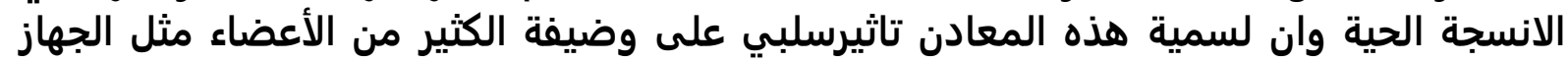

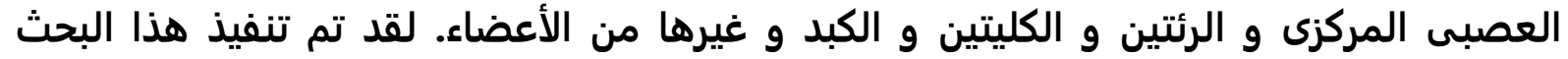

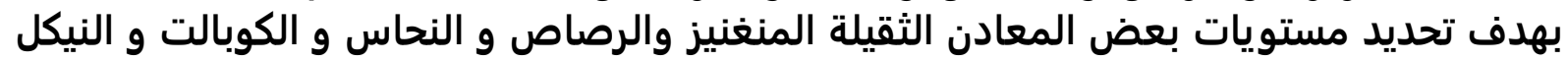

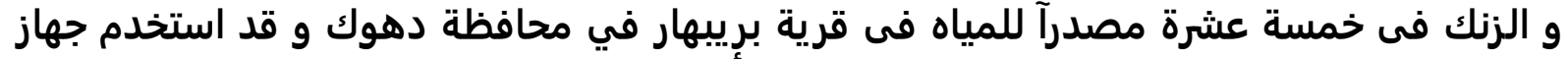

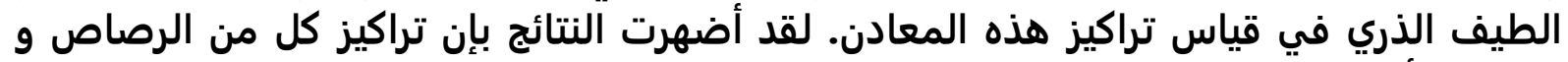

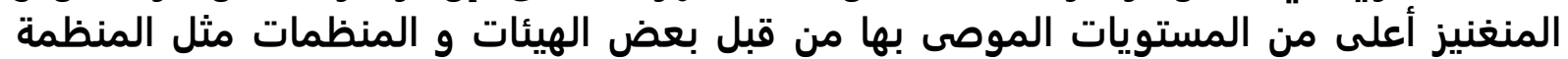

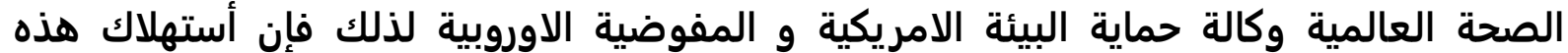

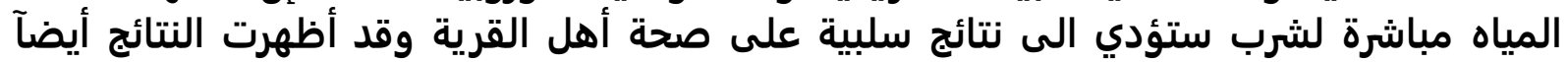

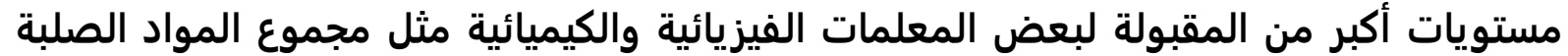
الذائبة و التوصيل الكهربائي في بعض مض مصادر مياه هذه القرية. 